\title{
Fertilizer Uptake, Partitioning, and Recovery in Container- Grown Common Hackberry (Celtis occidentalis) Trees
}

\author{
L.P. Werner and L.G. Jull
}

\begin{abstract}
Ammonium-nitrate $\left(\mathrm{NH}_{4} \mathrm{NO}_{3}\right)$ double enriched with the ${ }^{15} \mathrm{~N}$ isotope $(1.5$ atom \%) was used to evaluate fertilizer $\mathrm{N}$ recovery, $\mathrm{N}$ partitioning, and aboveground $\mathrm{N}$ status in container-grown common hackberry (Celtis occidentalis $\mathrm{L}$.) trees back-filled with native soil at Arlington, Wisconsin and Lisle, Illinois, U.S. Treatments consisted of $0,1.42 \mathrm{~g} \mathrm{~N}$ tree $^{-1}(0.05 \mathrm{oz})$ and $4.27 \mathrm{~g} \mathrm{~N}$ tree $^{-1}(0.15 \mathrm{oz})$, the area equivalent of 0 , 0.49 , and $1.47 \mathrm{~kg} \mathrm{~N} 100 \mathrm{~m}^{-2}\left(0,1\right.$, and $\left.3 \mathrm{lb} \mathrm{N} 1000 \mathrm{ft}^{-2}\right)$. Trees were harvested 14, 30, 60, and 90 days after fertilization. Fertilizer-induced changes in aboveground $\mathrm{N}$ status were significant only at the $4.27 \mathrm{~g} \mathrm{~N}$ tree $^{-1}(0.15 \mathrm{oz})$ treatment level. The amount of fertilizer $\mathrm{N}$ recovered in aboveground tissues increased with rate of application. Fertilizer $\mathrm{N}$ was preferentially partitioned to foliage and current season stem wood. The percentage of fertilizer recovered in aboveground tissues did not differ between the application rates, ranging from $15 \%-25 \%$ at Arlington, WI, and 5\%-9\% at Lisle, IL. Frost damage to the foliage at Lisle, IL may have resulted in location differences in aboveground biomass which affected fertilizer $\mathrm{N}$ uptake and recovery. These data suggest fertilizer $\mathrm{N}$ accumulated in nontarget sinks and/or were lost from the site of application at both rates of application.

Key Words. ANSI A-300; Fertilization; Landscape Trees; ${ }^{15} \mathrm{~N}$.
\end{abstract}

Applying nitrogen $(\mathrm{N})$ based fertilizer to landscape trees has been a common arboricultural practice since the early 1900s. Early research demonstrated $\mathrm{N}$ limitations in urban landscapes with increased tree growth following the addition of $\mathrm{N}$ fertilizers (Wyman 1936; Neely et al. 1965; Smith 1978; Neely 1980). These growthbased studies and the resulting nutrient management recommendations were later supported by reports of reduced rates of $\mathrm{N}$ mineralization in urban soils resulting from declines in microbial activity (White and McDonnell 1988), reduced organic $\mathrm{N}$ inputs associated with tree litter collection and removal (Werner 2000), and the accumulation of heavy metals (Kandeler et al. 1996).

Observed reductions in fertilizer use efficiency ( $\mathrm{g} \mathrm{N} / \mathrm{g}$ biomass) associated with step-wise increases in plant available $\mathrm{N}$ have indicated there is a physiological upper limit to the rate of application (Struve 1995; Rose 1999; Rose and Biernacka 1999). These findings suggest there is an increased potential for off-site losses or the partitioning of fertilizer $\mathrm{N}$ into nontarget sinks when rates of application exceed a plant's physiological need. In the late 1990s, landscape tree fertilization became a contentious environmental issue as annual $\mathrm{N}$ application rates consistent with tree growth studies were identified as potential nonpoint sources of surface and groundwater contamination (Perry and Hickman 1998; Miller 2003).

Nitrate $\left(\mathrm{NO}_{3}^{-}\right)$has been reported to accumulate below the effective rooting depth in agricultural fields when fertilizer applications exceeded total demand for $\mathrm{N}$ within the area of application. The accumulated $\mathrm{NO}_{3}^{-}$was susceptible to leaching during periods of saturated flow, with $\mathrm{N}$ losses proportional to the amount of surplus $\mathrm{N}$ (Masarik 2003). Similar increases in soil solution $\mathrm{NO}_{3}-\mathrm{N}$ have been observed under landscape trees and turfgrass receiving chronic fertilizer $\mathrm{N}$ additions, suggesting $\mathrm{N}$ inputs exceeded the site's physiological need and/or the ability to retain $\mathrm{N}$ and were susceptible to leaching (Werner 2000). The environmental ramifications associated with accumulations of fertilizer $\mathrm{N}$ in nontarget pools are serious, especially when application rates in excess of physiological need are applied on an annual basis (Perakis et al. 2005).

Concerns over ground and surface water contamination resulting from $\mathrm{N}$ fertilization of nursery trees (Colangelo and Brand 2001), fruit and citrus trees (Martinez et al. 2002; Scholberg et al. 2002), and turfgrass (Gross et al. 1990) resulted in the increased use of ${ }^{15} \mathrm{~N}$ as an isotopic tag to quantify fertilizer $\mathrm{N}$ recovery and define partitioning patterns. For example, whole-plant uptake efficiency (total $\mathrm{N}$ uptake/amount of $\mathrm{N}$ applied) in production apple trees (Malus sylvestris var. domestica Borkh.) was calculated to be $22 \%$ of the recommended application rate (Neilsen et al. 2001). These findings prompted changes in water management practices so as to increase the soil residency time of the fertilizer during periods of peak $\mathrm{N}$ demand. Similarly, a mass balance approach was used to quantify recovery from a single application, $49 \mathrm{~kg} \mathrm{ha}^{-1}$ (43 lbs $\mathrm{N}$ acre ${ }^{-1}$ ), of ${ }^{15} \mathrm{~N}$ enriched ammonium sulfate in Kentucky bluegrass (Poa pratensis L.) and perennial ryegrass (Lolium perenne L.) (Engelsjord et al. 2004). Maximum fertilizer $\mathrm{N}$ recovery rates of $79 \%$ and $91 \%$ were observed two days after application for perennial ryegrass and Kentucky bluegrass, respectively. One year after treatment, fertilizer recovery rates from the soil and aboveground tissues were approximately $70 \%$. The high recovery rates support claims that a judicious application of fertilizer N, $49 \mathrm{~kg} \mathrm{ha}^{-1}$ (43 lbs N acre ${ }^{-1}$ ), is not prone to leaching.

Comparatively, the majority of landscape tree fertilization research has focused on stimulating aboveground growth through experimentation with fertilizer formulation and method of delivery (van de Werken 1981; van de Werken 1984), rate of application 
(Smith 1978; Neely 1980), and season of application (Struve and Rose 1998; Rose 1999). Therefore, the objectives of this research were to quantify fertilizer recovery in aboveground tissues, describe fertilizer $\mathrm{N}$ partitioning patterns, and evaluate the effect of fertilization on the aboveground $\mathrm{N}$ status in common hackberry (Celtis occidentalis L.) using a ${ }^{15} \mathrm{~N}$ enriched fertilizer at the upper and lower rate limits for landscape trees as proposed in the ANSI A-300 (2004) standards. Recovery rates were calculated several times over the course of a single growing season and native soil was used as the rooting media to better simulate landscape soils.

\section{METHODS AND MATERIALS}

Common hackberry, a tree native to eastern and central U.S. and Canada, was used to evaluate fertilizer partitioning and recovery in aboveground biomass at Arlington, Wisconsin and Lisle, Illinois, U.S. This riparian species reaches a height of 15-21 m (50-70 $\mathrm{ft}$ ) at maturity, is tolerant of a wide range of soil types, $\mathrm{pH}$, moisture regimes, and air pollution. As a result, common hackberry is used extensively as a street, park, and landscape tree (Dirr 1998).

The Lisle, IL site is located on the grounds of The Morton Arboretum $\left(41^{\circ} \mathrm{N}-88^{\circ} \mathrm{W}\right)$ in northeastern Illinois. Mean growing season temperatures (April-September) range from $10-24^{\circ} \mathrm{C}$ $\left(50-75^{\circ} \mathrm{F}\right)$ and the area averages $929 \mathrm{~mm}$ (36.6 in) of precipitation per year (Illinois State Water Survey 2002). The study site was located in a cleared field formerly consisting of mixed hardwoods. Soils in the study site are Oxyaquic Hapludalfs, dominated by Ozaukee silt loam ( $32 \%$ sand, $19 \%$ clay, $49 \%$ silt), a moderately well-drained soil consisting of a thin silt cap over sand, gravel, silt and clay glacial till (USDA 2000). Average pH, percent soil organic matter (\% SOM), and cation exchange capacity (CEC) for the Lisle, IL study site were $6.9,3.8 \%$ and $13 \mathrm{cmol}$ $\mathrm{kg}^{-1}$ soil, respectively. Concentrations of phosphorus $(\mathrm{P})$, calcium $(\mathrm{Ca})$, potassium $(\mathrm{K})$, and magnesium $(\mathrm{Mg})$, within the soil at Lisle, IL were $20,1753,159$, and $458 \mathrm{mg} \mathrm{L}^{-1}$ (ppm), respectively.

The Arlington Horticulture Research Station, Arlington, WI $\left(43^{\circ} \mathrm{N}-89^{\circ} \mathrm{W}\right)$ study site is located in south-central Wisconsin. Mean growing season temperatures range from $14-21^{\circ} \mathrm{C}\left(57-70^{\circ} \mathrm{F}\right)$ and the area averages $833 \mathrm{~mm}$ (32.8 in) of precipitation per year (Wisconsin State Climatology Office 2002). The study site was formerly used for the production of agricultural crops. Soil in the study site is a Plano silt loam (Typic Argiudoll, 21\% sand, 16\% clay, $63 \%$ silt) that is moderately well-drained to well-drained, and possesses a silt cap approximately $102-152 \mathrm{~cm}$ (40-60 in) thick over a sand and gravel glacial till (USDA 1978). Average $\mathrm{pH}, \%$ SOM, and CEC were $6.2,3.0 \%$, and $13 \mathrm{cmol} \mathrm{kg}^{-1}$ soil, respectively. Additionally, concentrations of phosphorus $(\mathrm{P})$, calcium $(\mathrm{Ca})$, potassium $(\mathrm{K})$, and magnesium $(\mathrm{Mg})$, within the soil at Arlington, WI were $48.4,1770,164$, and $436 \mathrm{mg} \mathrm{L}^{-1}$ (ppm), respectively.

A randomized complete block design consisting of five blocks, three fertilizer treatment levels and four harvest periods was employed at each study location. On May 10 and May 16, 2002, sixty, $2.54 \mathrm{~cm}$ (1 in) caliper, container-grown, grafted trees from Bailey Nurseries, St. Paul, MN, were transplanted into $61 \mathrm{~cm}(24$ in) diameter Root-Control ${ }^{\mathrm{TM}}$ bags (Root Control Inc., Oklahoma City, OK) and backfilled with native soil at Lisle, IL and Arlington, WI, respectively. Blocks were aligned in an east-to-west direction. Spacing between blocks and between trees within a block was $3.05 \mathrm{~m}(10 \mathrm{ft})$. Within each of the five blocks, there was one tree per treatment level and harvest period combination (twelve trees per block). Treatments consisted of de-ionized water ( $0 \mathrm{~g}$ $\mathrm{N}), 1.42 \mathrm{~g} \mathrm{~N}(0.05 \mathrm{oz})$, and $4.27 \mathrm{~g} \mathrm{~N}(0.15 \mathrm{oz})$ per tree dissolved in $7.6 \mathrm{~L} \mathrm{(2} \mathrm{gal)} \mathrm{of} \mathrm{de-ionized} \mathrm{water} \mathrm{and} \mathrm{four} \mathrm{harvest} \mathrm{periods} \mathrm{(14,}$ 30, 60 and 90 days after treatment). Fertilizer treatments were the area equivalent of $0,0.49$ and $1.47 \mathrm{~kg} \mathrm{~N} 100 \mathrm{~m}^{-2}(0,1$ and $\left.3 \mathrm{lb} \mathrm{N} 1000 \mathrm{ft}^{-2}\right)$, respectively. Ammonium-nitrate $\left(\mathrm{NH}_{4} \mathrm{NO}_{3}\right)$ double enriched with the ${ }^{15} \mathrm{~N}$ isotope (1.5 atom \% for both the $\mathrm{NH}_{4}{ }^{+}$and $\mathrm{NO}_{3}{ }^{-}$) was applied at the aforementioned rates on June 12 and June 20, 2002 at Arlington, WI, and Lisle, IL, respectively. Root zones were hand-weeded to eliminate competition for fertilizer $\mathrm{N}$ throughout the study and supplemental irrigation was provided, as needed, to ensure $2.54 \mathrm{~cm}$ of water per week.

A composite of five, $2.54 \mathrm{~cm}$ by $25.4 \mathrm{~cm}$ (10 in) soil cores obtained from the east and west end of each block at the time of transplanting were analyzed at the University of WisconsinMadison Soil and Plant Analysis Laboratory (Verona, WI) to determine soil $\mathrm{pH}$ (1:1 water), soil organic matter (\% loss on ignition), $\mathrm{P}$ (Bray $\mathrm{P} 1), \mathrm{K}, \mathrm{Ca}$ and $\mathrm{Mg}(1.0 \mathrm{~N}$ ammonium acetate), and CEC by summation of extracted $\mathrm{K}, \mathrm{Ca}$, and $\mathrm{Mg}$.

Foliage $(\mathrm{F})$, current season stem wood $(\mathrm{Sc})$ consisting of the new terminal stem growth, stem wood (S), and roots (R) samples were collected at the time of transplanting to establish baseline total nitrogen and ${ }^{15} \mathrm{~N}$ atom $\%$ values. At each harvest period, the entire aboveground biomass was separated into foliage, current season stem wood, and stem wood. Stem samples used in analysis consisted of all stem tissue above the graft union. Total root biomass was not determined due to an inability to consistently separate the roots from the container growing medium. Root samples used in analysis consisted of approximately $30-50 \mathrm{~g}(1.05-1.76 \mathrm{oz})$ of woody and nonwoody roots obtained equally from the lower, middle, and upper portions of the root system. Root samples were rinsed twice for approximately $5 \mathrm{~s}$ per rinse with de-ionized water.

Tissue samples were dried at $60^{\circ} \mathrm{C}\left(140^{\circ} \mathrm{F}\right)$ until processing. Total dry weight of aboveground tissues used in calculating fertilizer recovery was determined just prior to grinding in a Wiley mill (Thomas-Wiley Laboratory Mills, Philadelphia, PA) to pass a $1 \mathrm{~mm}(0.04 \mathrm{in})$ sieve. A homogenized $1 \mathrm{~g}(0.035$ oz) subsample was pulverized in a Crescent "Wig-L-Bug" Dental Amalgamator (Crescent Dental Manufacturing, Chicago, IL) for $120 \mathrm{~s}$ using two, $5 \mathrm{~mm}$ (0.197 in) stainless steel ball bearings, at 5,000 rpm. Approximately $5 \mathrm{mg}(0.0002 \mathrm{oz})$ of pulverized tissue were combusted at $1020^{\circ} \mathrm{C}\left(1868^{\circ} \mathrm{F}\right)$ in a Carlo-Erba Carbon : Nitrogen analyzer (Carlo Erba, Milan, Italy) interfaced with a Europa Scientific TracerMass mass spectrometer (Crew, Cheshire, United Kingdom). Analysis consisted of total $\mathrm{N}$ and atom $\%{ }^{15} \mathrm{~N}$ on a percent dry weight basis. Quality control was verified by duplicate analysis every 10-12 samples. The percentage of fertilizer $\mathrm{N}$ recovered was calculated according to methods reported by Kraimer et al. (2001).

[Equation 1] N Recovery $=\frac{\sum N(A-B)}{F(C-D)}$

Where:

$\mathrm{N}=$ Weight of $\mathrm{N}(\mathrm{g})$ in a component tissue

$\mathrm{A}={ }^{15} \mathrm{~N} \%$ in fertilized tissue sample

$\mathrm{B}={ }^{15} \mathrm{~N} \%$ in tissue prior to fertilization

$\mathrm{C}={ }^{15} \mathrm{~N} \%$ in fertilizer

$\mathrm{D}=$ Natural abundance of ${ }^{15} \mathrm{~N}$ which is $0.366 \%$ (International 
Atomic Energy Agency 1983)

$\mathrm{F}=$ Grams of fertilizer

The percentage of nitrogen derived from fertilizer (NDFF) was adapted from equations developed by Hauck and Bremner (1976).

[Equation 2] $\quad \mathrm{NDFF}=\frac{A-B}{C-D}$

Where:

$A={ }^{15} \mathrm{~N} \%$ in fertilized tissue sample

$\mathrm{B}={ }^{15} \mathrm{~N} \%$ in tissue prior to fertilization

$\mathrm{C}={ }^{15} \mathrm{~N} \%$ in fertilizer

$\mathrm{D}=$ Natural abundance of ${ }^{15} \mathrm{~N}$ which is $0.366 \%$

Biomass weighted total $\mathrm{N}$ was calculated as follows:

[Equation 3] Weighted TN $=\sum\left(\%\right.$ total biomass $\left.{ }_{F, S c, S} \times \% \mathrm{TN}_{F, S c, S}\right)$

Where:

$F=$ foliage as a percent of total aboveground biomass $(\mathrm{g})$

$S c=$ current season stem wood as a percent of total aboveground biomass $(\mathrm{g})$

$S=$ stem wood as a percent of total aboveground biomass (g)

Treatment effects within a harvest period were determined using mixed model ANOVA procedures in SAS (Littell et al. 2004). Application rate was the fixed effect and treatment within a block was a random effect. Scatter plots of residuals versus predicted values and the Kolmogorov-Smirnov test were used to test assumptions of normality. The log likelihood test was used to select the appropriate analysis model. Statistical analysis on the percentage of NDFF was performed on arcsin square root transformed data because many of the data sets did not meet the assumption of equal variances. Comparisons of treatment effects were made using Fisher's least significant difference test with $P \leq 0.05$. References to percent changes resulting from increases in the rate of application are based upon back-transformed values.

\section{RESULTS AND DISCUSSION}

Just prior to transplanting, a late spring frost did extensive damage to the foliage at Lisle, IL which resulted in a second flush of new foliage. Consequently, biomass partitioning ( $\%$ of total aboveground dry weight) among the tissues was significantly different between the study site locations 14, 30, and 60 days after treatment. The percentage of total aboveground biomass accounted for by the foliage and current season stem wood at Arlington, WI was, on average, $84 \%$ and $78 \%$ higher than values observed at Lisle, IL during the 2002 growing season. The reduction in foliar biomass may have negatively affected fertilizer $\mathrm{N}$ acquisition and recovery at Lisle, IL. Similar results were observed by Kosola et al. (2001) who reported reduced uptake of $\mathrm{NO}_{3}^{-}$and $\mathrm{NH}_{4}{ }^{+}$in hybrid poplar (Populus $\times$canadensis Moench. 'Eugenei') following defoliation by gypsy moth (Lymantria dispar L.).

Additionally, foliar frost damage may have reduced root proliferation and growth within the Root Control ${ }^{\mathrm{TM}}$ bags. Root initiation and expansion requires a carbon (C) substrate, with the primary source being carbohydrates produced during photosynthesis within the leaves. The flush of new foliage may have resulted in a demand for $\mathrm{N}$ that occurred after the fertilizer application date and/or influenced carbohydrate allocation to the roots and subsequently, the capacity to acquire fertilizer N (Huett 1996; Kosola et al. 2001).

\section{Impact of Fertilization on Total N Concentration}

The rate of application significantly affected foliar total $\mathrm{N}$ concentration $[\mathrm{N}] 60$ days after treatment and was borderline significant $(P=0.052)$ at 30 days at Arlington, WI and 14 days after treatment at Lisle, IL (Table 1). At Arlington, WI, the $4.27 \mathrm{~g} \mathrm{~N}$ application rate increased foliar $\mathrm{N}$ by $57 \%$ and $11 \%$, relative to control trees and trees receiving $1.42 \mathrm{~g} \mathrm{~N}$, respectively, at 30 days after treatment (Figure 1). Similarly, increases of $20 \%$ and $9 \%$ were observed 60 days after fertilization in Arlington, WI for 4.27 $\mathrm{g} \mathrm{N}$ application rate. At Lisle, IL, foliar $\mathrm{N}$ at 14 days after treatment was $20 \%$ and $11 \%$ higher in trees receiving the $4.27 \mathrm{~g} \mathrm{~N}$ application rate, relative to control trees and trees receiving 1.42 $\mathrm{g} \mathrm{N}$, respectively. Increases in foliar $\mathrm{N}$ concentration have been shown to improve short-term photosynthetic efficiency ( $\mathrm{g}$ C fixed $\mathrm{m}^{-2}$ ) and net carbon assimilation, resulting in greater leaf area and enhanced aboveground biomass production (Gough et al. 2004). However, there is growing evidence to suggest there is a physiological threshold surrounding $\mathrm{N}$ accumulation in the foliage,

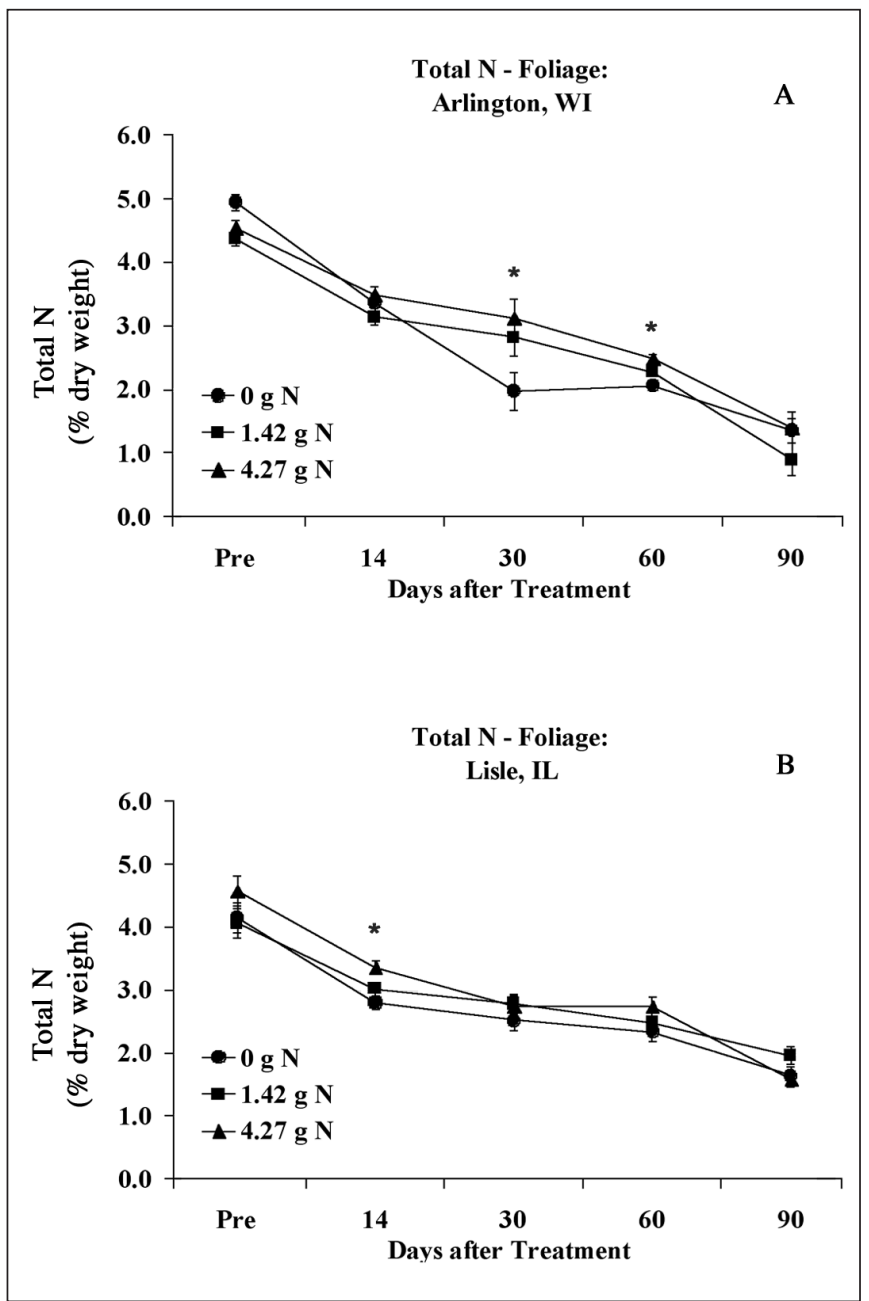

Figure 1. Total $[\mathrm{N}]$ in foliage of common hackberry at (A) Arlington, WI and (B) Lisle, IL in 2002. Symbols represent the mean $(n=5) \pm$ the adjusted standard error. Asterisk indicates significant difference at $\boldsymbol{P} \leq 0.05$ 
whereupon excess $\mathrm{N}$ accumulation diminishes both the photosynthetic capacity and the activation state of Rubisco (Manter et al. 2005). The elevated concentration of $\mathrm{N}$ in the foliage of trees receiving the $4.27 \mathrm{~g} \mathrm{~N}$ application rate suggests an enhanced capacity for growth, although there is no published data to indicate if the observed concentrations approached a physiological threshold.

Despite the treatment-induced effects, foliar total $[\mathrm{N}]$ declined throughout the study period. Foliar total $[\mathrm{N}]$ values 90 days after fertilization at Lisle, IL were $41 \%, 35 \%$, and $53 \%$ lower than values observed at 14 days for trees receiving $0,1.42 \mathrm{~g} \mathrm{~N}$, and $4.27 \mathrm{~g}$ $\mathrm{N}$, respectively. Similarly, at Arlington, WI, foliar total $[\mathrm{N}]$ at 90 days for trees receiving $0,1.42 \mathrm{~g} \mathrm{~N}$, and $4.27 \mathrm{~g} \mathrm{~N}$ were $59 \%, 71 \%$, and $59 \%$ lower than maximum values at 14 days. Seasonal declines in foliar total $[\mathrm{N}]$ are the product of $\mathrm{N}$ dilution resulting from an increase in leaf area due to cellular expansion, the accumulation of secondary metabolites associated with leaf maturation, and the export of $\mathrm{N}$ prior to leaf senescence (Escudero and Mediavilla 2003).

The rate of application did not affect total $\mathrm{N}$ in the current season stem wood at either location during any of the harvest periods. Maximum total $[\mathrm{N}]$ in current stem wood was observed prior to fertilization and decline substantially through 60 days after treatment (data not shown). At Arlington, WI, total [N] in the current season stem wood at 60 days was $36 \%, 28 \%$, and $25 \%$ lower than pre-treatment values for trees receiving no fertilizer $\mathrm{N}, 1.42 \mathrm{~g} \mathrm{~N}$, and $4.27 \mathrm{~g} \mathrm{~N}$, respectively. At Lisle, IL, declines of $30 \%, 31 \%$, and $42 \%$ were observed over the same period of time for current season stem wood. At both locations, total $[\mathrm{N}]$ in the current season stem wood increased between 60 and 90 days after treatment. Total $[\mathrm{N}]$ increased by $28 \%, 9 \%$, and $17 \%$ between 60 and 90 days at Arlington, WI in trees receiving no fertilizer $\mathrm{N}, 1.42 \mathrm{~g} \mathrm{~N}$, and $4.27 \mathrm{~g} \mathrm{~N}$, respectively. At Lisle, IL, current season stem wood increased by $25 \%, 11 \%$, and $19 \%$, respectively, between 60 and 90 days after treatment.

The rate of application significantly affected total $[\mathrm{N}]$ in stem wood 90 days after treatment at Arlington, WI only. At 90 days, total $[\mathrm{N}]$ in stem wood of trees receiving the $4.27 \mathrm{~g} \mathrm{~N}$ application rate was $19 \%$ and $36 \%$ higher than trees receiving no fertilizer $\mathrm{N}$ and those receiving the $1.42 \mathrm{~g} \mathrm{~N}$ treatment, respectively (Figure 2 ). There was no difference between the control trees and trees receiving $1.42 \mathrm{~g} \mathrm{~N}$. At Lisle, IL, the rate of application did not affect total $[\mathrm{N}]$ in stem wood tissues during any of the harvest periods. Independent of treatment level, total $[\mathrm{N}]$ in stem wood declined substantially at both locations during the period of time between pre-treatment sampling and the 14 days after fertilization harvest period. Such early season declines have been shown to be the result of the remobilization of stored $\mathrm{N}$, primarily from perennial tissues, to support early season growth (Neilsen et al. 2001). Total $[N]$ in stem wood at Lisle, IL was substantially and consistently lower than those observed at Arlington, WI, suggesting stored $\mathrm{N}$ may have been further depleted to support the second flush of foliage. These observations are consistent with findings surrounding changes in $\mathrm{N}$ partitioning and acquisition patterns following defoliation. In red oak (Quercus rubra L.) trees, Lovett and Tobiessen (1993) observed that the sources of $\mathrm{N}$ to support growth after defoliation included both acquiring soil derived $\mathrm{N}$ and remobilizing $\mathrm{N}$ stored from stem and root tissues.

The trend in the data for total $[\mathrm{N}]$ in current season stem wood and stem wood are consistent with theories surrounding the resorption and storage of $\mathrm{N}$ removed from the leaf prior to senescence. Gomez and Faurobert (2002) found that resorbed foliar N was

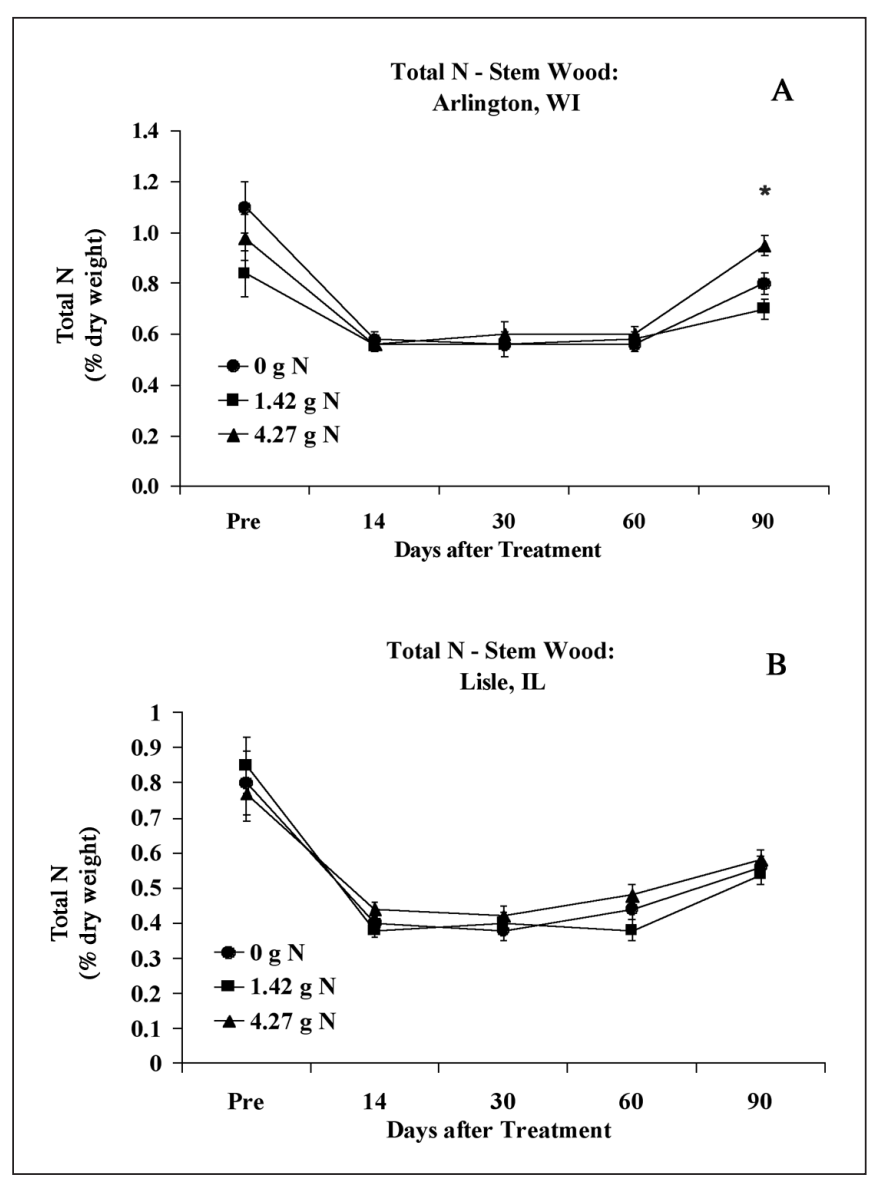

Figure 2. Total $[\mathrm{N}]$ in stem wood of common hackberry at (A) Arlington, WI, and (B) Lisle, IL in 2002. Symbols represent the mean $(n=5) \pm$ adjusted standard error. Asterisk indicates significant difference at $\boldsymbol{P} \leq \mathbf{0 . 0 5}$.

stored, to a great extent, as low molecular weight proteins within the radial parenchyma and phloem in the stem wood of peach (Prunus persica L. Batsch) trees. However, the extent of the increases in total $[\mathrm{N}]$ during the early stages of dormancy does not appear to be correlated to the rate of application. This lack of consistency among treatment levels may have been the result of $\mathrm{N}$ dilution associated with using the entire volume of the stem to prepare a sample for analysis or it may be an artifact associated with the 90 days sampling period. Werner (2008) observed continued and substantial increases in total $[\mathrm{N}]$ through 150 days after fertilization in a complimentary field study using common hackberry trees.

Total $[\mathrm{N}]$ in root tissues of trees receiving $1.42 \mathrm{~g} \mathrm{~N}$ was $55 \%$ and $31 \%$ higher than control trees 30 and 90 days after treatment, respectively, at Arlington, WI (Figure 3). During these same harvest periods, root total $[\mathrm{N}]$ in trees receiving $4.27 \mathrm{~g} \mathrm{~N}$ increased by $70 \%$ and $41 \%$, respectively, over values observed in control trees. The observed increases in root total $[\mathrm{N}]$ of fertilized trees during these harvest periods suggest either a surplus of $\mathrm{N}$ that was stored in the roots and/or the incorporation of fertilizer $\mathrm{N}$ into the growth and development of new roots (Pregitzer et al. 1990). Hackberry's indeterminate growth pattern, the almost complete abscission of leaves at 90 days after treatment in Arlington, WI, and a continued decline in total $[\mathrm{N}]$ in the root tissues of control trees, suggests fertilization resulted in a surplus of 
fertilizer $\mathrm{N}$ that was stored in root tissues during periods of low aboveground demand (i.e., cessation of active growth cycles).

At 14 days after treatment in Lisle, IL, total $[\mathrm{N}]$ in the root tissues of trees receiving $1.42 \mathrm{~g} \mathrm{~N}$ was $25 \%$ and $26 \%$ higher than values observed in trees receiving $4.27 \mathrm{~g} \mathrm{~N}$ and the control trees, respectively. The lack of significant difference among treatment levels during the remaining harvest periods at Lisle, IL may be attributed to a persistent need for $\mathrm{N}$ resulting from the second flush of foliage. This conclusion is supported by substantially lower pre-treatment total $[\mathrm{N}]$ values, relative to those observed at Arlington, WI, and a continued decline in total $[\mathrm{N}]$ throughout the study period for all treatment levels.

The rate of application significantly affected biomass weighted aboveground total [N] (Equation 3) 60 days after treatment at both Arlington, WI and Lisle, IL. At Arlington, WI, the biomass weighted aboveground total $[\mathrm{N}]$ at 60 days after treatment for trees receiving $4.27 \mathrm{~g} \mathrm{~N}$ was $22 \%$ greater than both the control trees and trees receiving the $1.42 \mathrm{~g} \mathrm{~N}$ treatment (data not shown). At 60 days in Lisle, IL, the biomass weighted aboveground total $[\mathrm{N}]$ in trees receiving $1.42 \mathrm{~g} \mathrm{~N}$ was $11 \%$ lower than values observed in control trees and $20 \%$ lower than trees receiving the $4.27 \mathrm{~g} \mathrm{~N}$ treatment. Previous studies have demon-

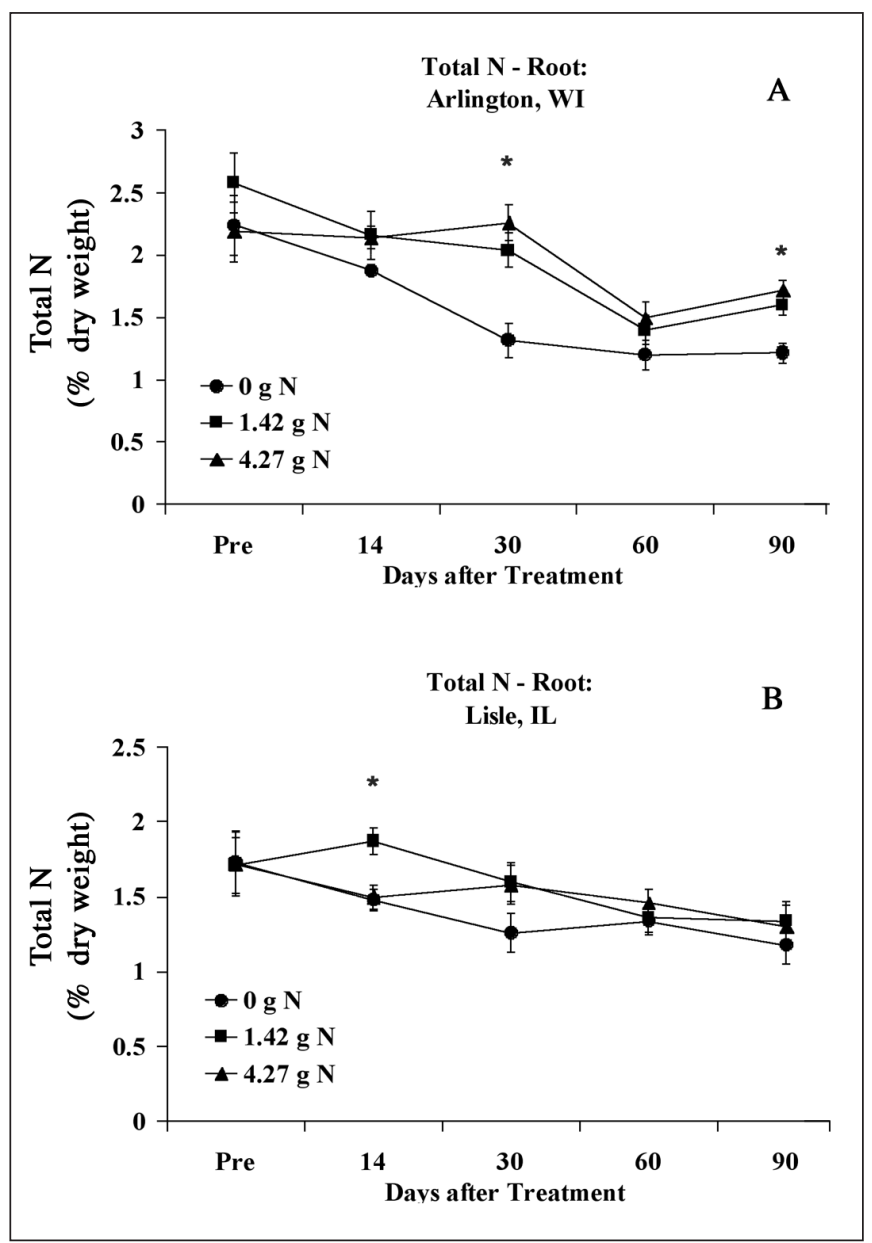

Figure 3. Total $[\mathrm{N}]$ in root tissues of common hackberry at (A) Arlington, WI, and (B) Lisle, IL in 2002. Symbols represent the mean $(n=5) \pm$ adjusted standard error. Asterisk indicates significant difference at $\boldsymbol{P} \leq \mathbf{0 . 0 5}$. strated dormant season whole plant total N status in seedlings is positively correlated with future growth (Struve 1995; Cornelissen et al. 1997; Rose and Biernacka 1999). However, data from this study suggests fertilization had no significant effect on the whole plant [N] status upon entering dormancy (e.g., 90 days after treatment). The lack of treatment difference at 90 days or the inability to detect differences may, however, be the result of utilizing larger plants to study the effects of fertilization on whole plant $[\mathrm{N}]$ status. Larger plants typically possess greater percentages of metabolically inactive tissue relative to their total aboveground biomass (Meerts 2002). Nitrogen tends to accumulate in metabolically active sites within the tree, therefore, increases in the amount of inactive tissue relative to the whole plant biomass may have diluted the whole plant total $[\mathrm{N}]$ status.

\section{N Partitioning}

Foliage and stem wood were the largest $\mathrm{N}$ sinks (\% of aboveground $\mathrm{N}$ ) at both locations (Table 1; Table 2). At Arlington, WI, approximately $49 \%, 4 \%$, and $46 \%$ of the $\mathrm{N}$ in aboveground tissues was contained in the foliage, current season stem wood, and stem wood, respectively. At Lisle, IL, the foliage, current season wood, and stem wood accounted for $40 \%, 4 \%$, and $56 \%$ of the aboveground $\mathrm{N}$, respectively. With the exceptions of foliage at 30 days after fertilization at Arlington, WI, and current season stem wood at 90 days at Lisle, IL, the rate of application did not affect the partitioning of $\mathrm{N}$ among the tissues. At 30 days, the percentage of $\mathrm{N}$ in foliar tissues receiving $4.27 \mathrm{~g}$ $\mathrm{N}$ was $21 \%$ and $11 \%$ greater than trees receiving 0 or $1.42 \mathrm{~g} \mathrm{~N}$, respectively (data not shown). In Lisle, IL, 90 days after treatment, total $\mathrm{N}$ in the current season stem wood of trees receiving $4.27 \mathrm{~g}$ was $25 \%$ higher than values observed in control trees and $67 \%$ higher than trees receiving $1.42 \mathrm{~g} \mathrm{~N}$. At both locations, stem wood accounted for an increasingly larger percentage of the aboveground N 60 and 90 days after treatment. These temporal shifts in partitioning patterns are associated with the retrieval and storage of $\mathrm{N}$ removed from leaves prior to abscission.

\section{Nitrogen Derived from Fertilizer}

Results involving nitrogen derived from fertilizer (NDFF), fertilizer $\mathrm{N}$ partitioning, and fertilizer recovery were based on increases in ${ }^{15} \mathrm{~N}$ relative to baseline ${ }^{15} \mathrm{~N}$ values. The observed increases in ${ }^{15} \mathrm{~N}$ were the result of applying a fertilizer enriched with ${ }^{15} \mathrm{~N}$. Consequently, control trees are excluded from the computations and subsequent discussions.

At both locations, the percent NDFF (Equation 2) in aboveground tissues and roots increased significantly with increasing rates of application (Table 3). At both locations, the percent NDFF in tissues of trees receiving $4.27 \mathrm{~g} \mathrm{~N}$ was three times greater than values observed in trees receiving $1.42 \mathrm{~g} \mathrm{~N}$ (Table 4). Independent of application rate and location, the largest percent NDFF was found in aboveground tissues developed during the current growing season, specifically, the foliage and current season stem wood.

Trends in foliar NDFF differed between the two locations. At Arlington, WI, fertilizer $\mathrm{N}$ tended to accumulate in the foliage through 30 days after treatment, then declined. At Lisle, IL, the percent NDFF in the foliage generally declined, although there was slight increases in the percent NDFF between the 60 and 90 days harvest periods. The observed declines at Lisle, IL may be the result of ${ }^{15} \mathrm{~N}$ dilution associated with a continued demand for $\mathrm{N}$ to support the second flush of foliage and/or leaf expansion and maturation. 
Table 1. Analysis of Variance (ANOVA) P-values for the effect of application rate on total $\mathrm{N}$ concentration (N), weighted total (N), and N partitioning in common hackberry tissues at Arlington, WI, and Lisle, IL in 2002.

\begin{tabular}{|c|c|c|c|c|c|c|c|c|c|}
\hline \multirow[b]{2}{*}{ Parameter } & \multirow[b]{2}{*}{ Tissue Type } & \multicolumn{4}{|c|}{$\begin{array}{c}\text { Arlington, WI } \\
\text { Days after Fertilization }\end{array}$} & \multicolumn{4}{|c|}{$\begin{array}{c}\text { Lisle, IL } \\
\text { Days after Fertilization }\end{array}$} \\
\hline & & 14 & 30 & 60 & 90 & 14 & 30 & 60 & 90 \\
\hline \multirow{3}{*}{$\begin{array}{l}\text { Total }[\mathrm{N}] \\
\text { (\% dry weight) }\end{array}$} & Foliage & $0.144^{z}$ & 0.052 & $<0.001$ & 0.285 & 0.012 & 0.485 & 0.196 & 0.143 \\
\hline & Stem Wood & 0.859 & 0.804 & 0.679 & 0.037 & 0.101 & 0.661 & 0.079 & 0.641 \\
\hline & Root & 0.058 & 0.001 & 0.263 & 0.002 & 0.021 & 0.165 & 0.607 & 0.656 \\
\hline $\begin{array}{l}\text { Weighted Total }[\mathrm{N}] \\
\text { (\% dry weight) }\end{array}$ & $\begin{array}{l}\text { All Aboveground } \\
\text { Tissues }{ }^{y}\end{array}$ & 0.198 & 0.212 & 0.006 & 0.697 & 0.505 & 0.269 & 0.045 & 0.841 \\
\hline \multirow[t]{3}{*}{ N Partitioning } & Foliage & 0.670 & 0.005 & 0.747 & 0.939 & 0.189 & 0.947 & 0.929 & 0.983 \\
\hline & Current Stem Wood & 0.677 & 0.813 & 0.229 & 0.804 & 0.242 & 0.840 & 0.793 & 0.049 \\
\hline & Stem Wood & 0.095 & 0.061 & 0.362 & 0.908 & 0.263 & 0.923 & 0.930 & 0.955 \\
\hline
\end{tabular}

${ }^{2}$ All values are means of $n=5$.

${ }^{y}$ Sum of percent $\mathrm{N}$ in foliage, current season stem wood, stem wood $\times$ percent aboveground biomass (dry weight) represented by each of these tissues.

Table 2. Total $\mathrm{N}$ partitioning, as a percentage of total $\mathrm{N}$ in all aboveground tissues, in common hackberry at Arlington, WI, and Lisle, IL in 2002.

\begin{tabular}{|c|c|c|c|c|c|c|c|c|c|}
\hline \multirow[b]{2}{*}{ Trt (g) } & \multirow[b]{2}{*}{ Tissue Type } & \multicolumn{4}{|c|}{$\begin{array}{c}\text { Arlington, WI } \\
\text { Days after Fertilization }\end{array}$} & \multicolumn{4}{|c|}{$\begin{array}{c}\text { Lisle, IL } \\
\text { Days after Fertilization }\end{array}$} \\
\hline & & 14 & 30 & 60 & 90 & 14 & 30 & 60 & 90 \\
\hline \multirow[t]{2}{*}{$\overline{0}$} & Foliage & 51 & 47 & 47 & 6 & 38 & 43 & 38 & 20 \\
\hline & Stem Wood & 45 & 49 & 48 & 86 & 58 & 53 & 58 & 75 \\
\hline \multirow[t]{3}{*}{1.42} & Foliage & 49 & 52 & 46 & 5 & 42 & 42 & 37 & 20 \\
\hline & Current Stem Wood & 4 & 3 & 4 & 9 & 5 & 5 & 4 & 3 \\
\hline & Stem Wood & 47 & 45 & 50 & 86 & 53 & 53 & 59 & 77 \\
\hline \multirow{2}{*}{4.27} & Current Stem Wood & 4 & 3 & 6 & 9 & 6 & 4 & 4 & 5 \\
\hline & Stem Wood & 42 & 42 & 47 & 87 & 58 & 52 & 60 & 75 \\
\hline
\end{tabular}

Table 3. Analysis of Variance (ANOVA) P-values for the effect of $1.42 \mathrm{~g} \mathrm{~N}$ and $4.27 \mathrm{~g} \mathrm{~N}$ per tree on percent nitrogen derived from fertilizer (NDFF) and fertilizer N recovery in common hackberry tissues at Arlington, WI, and Lisle, IL in 2002.

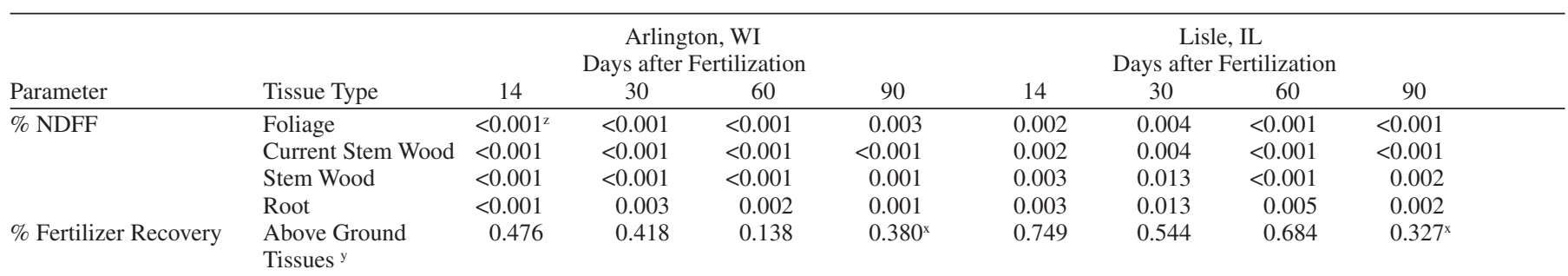

${ }^{\mathrm{z}}$ All values are means of $\mathrm{n}=5$

${ }^{y}$ Sum of fertilizer recovery in foliage, current season stem wood, and stem wood.

${ }^{x}$ Sum of fertilizer recovery in remaining foliage, current season stem wood and stem wood.

Table 4. Percent nitrogen derived from fertilizer (NDFF) in common hackberry tissues at Arlington, WI, and Lisle, IL in 2002.

\begin{tabular}{|c|c|c|c|c|c|c|c|c|c|}
\hline \multirow[b]{2}{*}{ Tissue } & \multirow[b]{2}{*}{$\operatorname{Trt}(\mathrm{g})$} & \multicolumn{4}{|c|}{$\begin{array}{c}\text { Arlington, WI } \\
\text { Days after Treatment }\end{array}$} & \multicolumn{4}{|c|}{$\begin{array}{c}\text { Lisle, IL } \\
\text { Days after Treatment }\end{array}$} \\
\hline & & 14 & 30 & 60 & 90 & 14 & 30 & 60 & 90 \\
\hline Foliage & $\begin{array}{l}1.42 \\
4.27\end{array}$ & $\begin{array}{l}6.5^{\text {zyx }} \\
16.7^{2}\end{array}$ & $\begin{array}{r}9.4 \\
24.7\end{array}$ & $\begin{array}{r}7.7 \\
20.1\end{array}$ & $\begin{array}{r}5.2 \\
18.0\end{array}$ & $\begin{array}{r}6.8 \\
19.7\end{array}$ & $\begin{array}{r}4.9 \\
18.3\end{array}$ & $\begin{array}{r}4.7 \\
12.4\end{array}$ & $\begin{array}{r}2.4 \\
14.3\end{array}$ \\
\hline Current Stem Wood & $\begin{array}{l}1.42 \\
4.27\end{array}$ & $\begin{array}{r}5.3 \\
16.7\end{array}$ & $\begin{array}{r}7.7 \\
20.9\end{array}$ & $\begin{array}{r}6.2 \\
14.7\end{array}$ & $\begin{array}{r}5.4 \\
16.9\end{array}$ & $\begin{array}{r}5.7 \\
15.6\end{array}$ & $\begin{array}{r}3.6 \\
13.8\end{array}$ & $\begin{array}{l}4.1 \\
9.4\end{array}$ & $\begin{array}{r}2.6 \\
11.2\end{array}$ \\
\hline Stem Wood & $\begin{array}{l}1.42 \\
4.27\end{array}$ & $\begin{array}{l}2.0 \\
6.1\end{array}$ & $\begin{array}{r}4.0 \\
13.0\end{array}$ & $\begin{array}{r}4.0 \\
11.9\end{array}$ & $\begin{array}{r}4.5 \\
13.7\end{array}$ & $\begin{array}{l}1.2 \\
4.3\end{array}$ & $\begin{array}{l}1.0 \\
4.1\end{array}$ & $\begin{array}{l}1.4 \\
4.1\end{array}$ & $\begin{array}{l}1.3 \\
5.4\end{array}$ \\
\hline Root & $\begin{array}{l}1.42 \\
4.27\end{array}$ & $\begin{array}{r}5.3 \\
15.2\end{array}$ & $\begin{array}{r}7.0 \\
18.6\end{array}$ & $\begin{array}{r}7.3 \\
18.1\end{array}$ & $\begin{array}{r}6.4 \\
14.2\end{array}$ & $\begin{array}{l}1.7 \\
4.4\end{array}$ & $\begin{array}{l}1.6 \\
4.1\end{array}$ & $\begin{array}{l}2.8 \\
5.5\end{array}$ & $\begin{array}{l}1.6 \\
6.9\end{array}$ \\
\hline
\end{tabular}

${ }^{\mathrm{z}}$ Values are the adjusted means of $\mathrm{n}=5$.

y Back-transformed values.

${ }^{\mathrm{x}}$ All treatment comparisons within a tissue type were significant at $P \leq 0.01$ for all harvest periods. 
The percent NDFF in the current season stem wood of trees receiving the $1.42 \mathrm{~g} \mathrm{~N}$ application rate nearly mirrored the trends in foliar NDFF at both locations. At Arlington, WI, maximum NDFF in current season stem wood occurred 30 days after treatment in trees receiving $1.42 \mathrm{~g} \mathrm{~N}$ or $4.27 \mathrm{~g} \mathrm{~N}, 7.7 \%$ and $20.9 \%$, respectively. At Lisle, IL, maximum current season stem wood NDFF occurred at 14 days after treatment at both rates of application. Additionally, at Lisle, IL, the percent NDFF in current season stem wood of trees receiving $4.27 \mathrm{~g}$ $\mathrm{N}$ increased by $19.1 \%$ between 60 and 90 days after treatment.

In stem wood, maximum percent NDFF for trees receiving the $4.27 \mathrm{~g} \mathrm{~N}$ treatment occurred 90 days after fertilization at Arlington, WI (13.7\%), and Lisle, IL (5.4\%). Relative to values at 14 days, the percent NDFF in stem wood at 90 days in trees receiving $4.27 \mathrm{~g} \mathrm{~N}$ increased by $125 \%$ and $25 \%$ at Arlington, WI and Lisle, IL, respectively. Maximum NDFF in the stem wood of trees receiving $1.42 \mathrm{~g} \mathrm{~N}$ occurred at 90 days (4.5\%) and 60 days $(1.4 \%)$ after treatment at Arlington, WI and Lisle, IL, respectively. Between 14 and 90 days after treatment, the percent NDFF in stem wood increased by $10 \%$ at Arlington, WI. There was little change (1.2\% versus $1.3 \%)$ in the percent NDFF in stem wood at Lisle, IL between these two harvest periods.

The maximum percent NDFF in root tissues of trees receiving $1.42 \mathrm{~g} \mathrm{~N}$ occurred 60 days after treatment at Arlington, WI and Lisle, IL, $7.3 \%$ and $2.8 \%$, respectively (Table 3). Maximum values for trees receiving $4.27 \mathrm{~g} \mathrm{~N}$ occurred at 30 days in Arlington, WI (18.6\%), and at 90 days in Lisle, IL (6.9\%). Throughout the remaining harvest periods, root NDFF remained fairly constant at Arlington, WI. However, between 30 and 60 days after treatment, root NDFF at Lisle, IL increased by $70 \%$ and $34 \%$ in trees receiving the $1.42 \mathrm{~g} \mathrm{~N}$ and $4.27 \mathrm{~g} \mathrm{~N}$ treatments, respectively.

The combination of increases in the percent NDFF in stem wood, particularly in the $4.27 \mathrm{~g} \mathrm{~N}$ treatment level and declines in the percent NDFF in foliage at 90 days is consistent with theories of $\mathrm{N}$ conservation in higher plants growing in an $\mathrm{N}$ limited environment. Research found approximately $50 \%$ of foliar $\mathrm{N}$ is removed prior to abscission and subsequently stored as low molecular weight proteins in stem and root tissues (Chapin and Kedrowski 1983; Aerts 1996). Data from this study indicate increasing rates of application consistently enhances fertilizer $\mathrm{N}$ accumulation in the foliage. However, the amount of fertilizer $\mathrm{N}$ removed from the foliage during leaf senescence is not consistent across the treatment levels. Relative to maximum values observed during the growing season (14-60 days after treatment), the percent NDFF in the foliage of trees receiving $4.27 \mathrm{~g} \mathrm{~N}$ declined by $27 \%$ at 90 days after treatment in both locations. In contrast, foliar NDFF at 90 days in trees receiving the $1.42 \mathrm{~g} \mathrm{~N}$ rate of application was $44 \%$ lower than maximum growing season values at Arlington, WI, and 58\% lower at Lisle, IL. However, at both locations and across the treatment levels, there were consistent declines in foliar total $[\mathrm{N}]$. Consequently, these data suggest trees receiving the high rate of application tended to lose more fertilizer $\mathrm{N}$ in the leaf litter. The fertilizer $\mathrm{N}$ contained within the leaf litter likely consists of structural proteins associated with new growth or photosynthetic proteins trapped in the foliage when the abscission layer was activated (Escudero and Mediavilla 2003; Hoch et al. 2003). These findings support Aerts (1996) conclusion that increasing the level of available $\mathrm{N}$ would either suppress or have no effect upon the amount of $\mathrm{N}$ removed from leaves prior to senescence.

At both locations and rates of application, $61 \%-78 \%$ of the fertilizer $\mathrm{N}$ that accumulated in aboveground tissues was partitioned to the foliage 14, 30, and 60 days after fertilization (Table 5). At 90 days after treatment, the percentage of aboveground fertilizer $\mathrm{N}$ accumulation in the foliage declined substantially in both treatment levels and locations. These reductions, particularly at 90 days after treatment, may be attributed to leaf loss and the onset of leaf senescence. Declines in the foliar contribution to aboveground fertilizer $\mathrm{N}$ accumulation coincided with increases in fertilizer $\mathrm{N}$ accumulation in stem wood in all treatment combinations at both locations and all rates of application. These observations are consistent with patterns of internal $\mathrm{N}$ cycling and storage (Brinkman and Boerner 1994; Aerts 1996).

\section{Fertilizer Recovery (\% of N Applied)}

The inability to consistently separate root tissues from the rooting medium prevented the determination of fertilizer $\mathrm{N}$ recovery in the root system. As a result, fertilizer $\mathrm{N}$ recovery is presented only for the aboveground tissues. Within both locations, there were no significant differences in the percentage of fertilizer $\mathrm{N}$ recovered between the $1.42 \mathrm{~g} \mathrm{~N}$ and $4.27 \mathrm{~g} \mathrm{~N}$ application rates in any of the harvest periods (Table 2). Pre-senescent (before 90 days after treatment), back-transformed, recovery rates in aboveground tissues ranged from $15 \%-25 \%$ at Arlington, WI, and 5\%-10\% at Lisle, IL (Figure 4). While reported, the extent of leaf senescence and loss at 90 days after treatment, particularly at Arlington, WI, prevented a meaningful interpretation of fertilizer $\mathrm{N}$ recovery. At Arlington, WI, maximum recovery rates occurred at 30 days for the $1.42 \mathrm{~g} \mathrm{~N}$ treatment $(22.3 \%)$ and at 60 days for the $4.27 \mathrm{~g}$ $\mathrm{N}$ treatment $(25.1 \%)$. At Lisle, IL, maximum recovery rates for trees receiving the $1.42 \mathrm{~g} \mathrm{~N}$ and $4.27 \mathrm{~g} \mathrm{~N}$ application rates occurred 30 days after fertilization, $9.4 \%$ and $7.7 \%$, respectively.

The range of recovery rates for both treatments at Arlington, WI were slightly higher than fertilizer $\mathrm{N}$ recovered in a lodgepole pine (Pinus contorta Dougl. ex Loud.) (Preston and Mead 1994) and black spruce [Picea mariana (Mill.) BSP] (Salifu and Timmer 2003), comparable to fertilizer recovery rates observed in pecan [Carya illinoinensis (Wangenh.) K. Koch]

Table 5. Percent applied fertilizer N partitioned to aboveground common hackberry tissues at Arlington, WI, and Lisle, IL in 2002.

\begin{tabular}{|c|c|c|c|c|c|c|c|c|c|}
\hline \multirow[b]{2}{*}{ Tissue } & \multirow[b]{2}{*}{$\operatorname{Trt}(\mathrm{g})$} & \multicolumn{4}{|c|}{$\begin{array}{c}\text { Arlington, WI } \\
\text { Days after Fertilization }\end{array}$} & \multicolumn{4}{|c|}{$\begin{array}{c}\text { Lisle, IL } \\
\text { Days after Fertilization }\end{array}$} \\
\hline & & 14 & 30 & 60 & 90 & 14 & 30 & 60 & 90 \\
\hline Foliage & 1.42 & $11.4^{\mathrm{z}}$ & 15.7 & 13.2 & 1.3 & 5.8 & 6.2 & 3.4 & 1.5 \\
\hline Stem Wood & 1.42 & 3.4 & 6.0 & 7.6 & 8.4 & 1.3 & 1.2 & 1.4 & 2.2 \\
\hline Foliage & 4.27 & 10.9 & 17.4 & 15.2 & 0.7 & 4.8 & 6.0 & 3.4 & 2.2 \\
\hline Current Stem Wood & 4.27 & 0.8 & 0.9 & 1.0 & 1.1 & 0.6 & 0.5 & 0.3 & 0.4 \\
\hline Stem & 4.27 & 3.1 & 6.4 & 8.7 & 9.2 & 1.6 & 1.6 & 1.8 & 2.9 \\
\hline
\end{tabular}

${ }^{\mathrm{z}}$ Values are means of $\mathrm{n}=5$. 


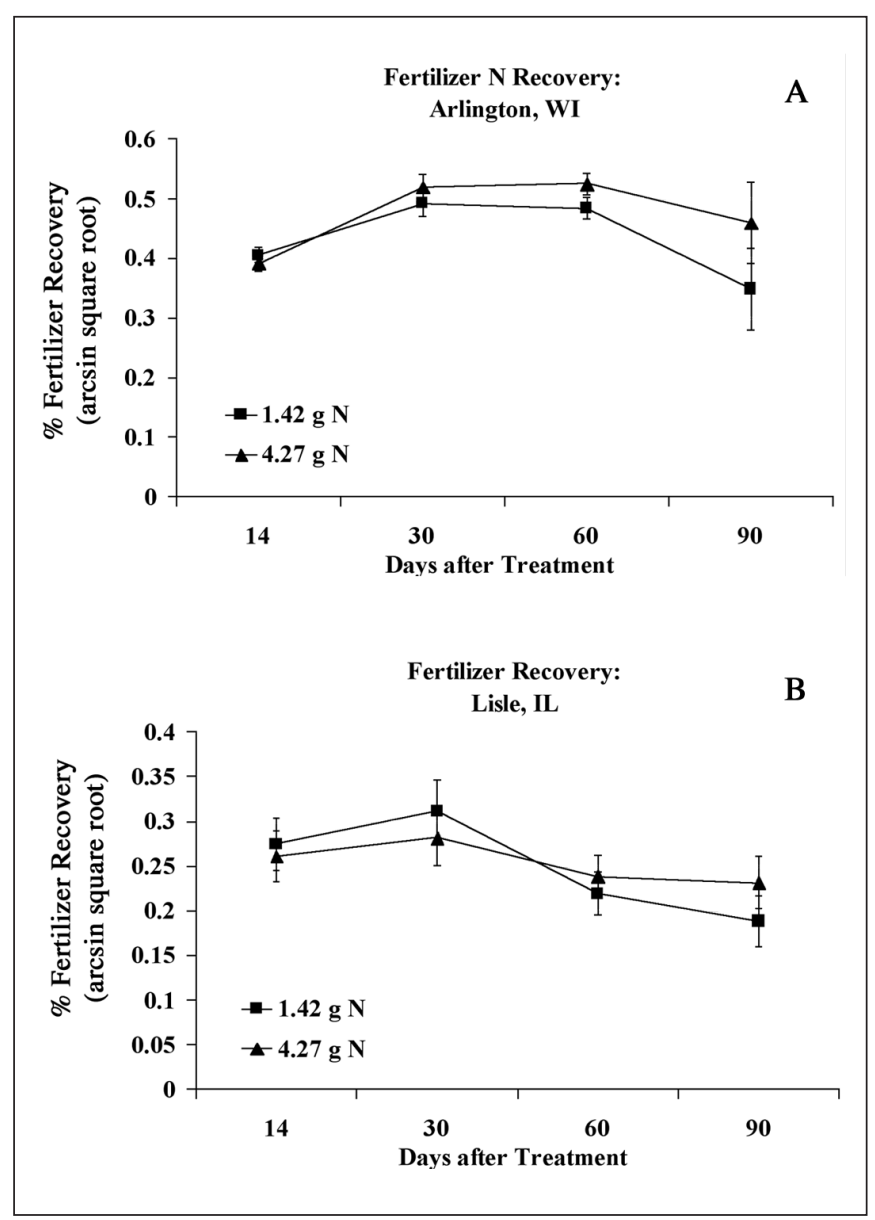

Figure 4. Percent fertilizer recovery in aboveground tissues of common hackberry at (A) Arlington, WI, and (B) Lisle, IL in 2002. Symbols represent the mean $(n=5) \pm$ the adjusted standard error. Scales on the y-axis are different.

(Kraimer et al. 2001), and substantially less than 50\%-60\% fertilizer $\mathrm{N}$ recovery rates in fruit-bearing orange trees [Citrus sinensis (L.) Osbeck.] (Feigenbaum et al. 1987) and Kentucky bluegrass (Poa pratensis L.) (Horgan et al. 2002). Recovery rates at Lisle, IL for both treatment levels were lower than all cited studies, including those involving conifers.

It is important to recognize that the reported fertilizer recovery rates do not include fertilizer $\mathrm{N}$ accumulation in the root system. A number of studies have indicated significant accumulations of $\mathrm{N}$ in root tissues, particularly at high rates of applications (Warren 1993; Mattos et al. 2003). The percent NDFF in root tissues at both locations were only slightly lower than values observed in the foliage and current season stem wood, indicating fertilizer $\mathrm{N}$ recovery at the whole plant level is significantly higher than what is reported for aboveground tissues.

Despite the observed differences in aboveground biomass between the respective locations, the treatment-induced trends in the percent NDFF and fertilizer N recovery were remarkably consistent on both a mass and percent basis. This study demonstrated fertilizer $\mathrm{N}$ uptake at application rates recommended under the ANSI A-300 standards were proportional, but not equal to, the amount of fertilizer $\mathrm{N}$ applied. Fertilization was also demonstrated to enhance the overall aboveground $\mathrm{N}$ status, resulting primarily from increases in foliar total $[\mathrm{N}]$. To a degree, increases in foliar total $[\mathrm{N}]$ status enhance photosynthetic capacity and the ability to acquire atmospheric carbon. However, $75 \%$ or more of applied fertilizer $\mathrm{N}$ could not be accounted for in aboveground biomass, regardless of the rate of application. It must be stressed that whole-plant fertilizer $\mathrm{N}$ recovery rates, which include roots, were unquestionably greater than the reported aboveground tissue recovery rates. However, substantial increases in fertilizer $\mathrm{N}$ recovery based on the observed concentrations of $\mathrm{N}$ and the percentages of NDFF in root tissues would require dramatic, and somewhat improbable, changes in the root-to-shoot ratio (Harris 1992; Ågren and Franklin 2003). Consequently, regardless of the rate of application substantial amounts of fertilizer $\mathrm{N}$ appears to accumulate in nontarget sinks (e.g., soil microbial biomass), or is potentially lost from the system via leaching or gaseous emissions.

\section{CONCLUSION}

In all tissue types, there were proportional increases in the percent nitrogen derived from fertilizer. On both a mass and percentage basis, the vast majority of fertilizer $\mathrm{N}$ in aboveground tissues was preferentially partitioned to the foliage. However, only the highest rate of application appeared to produce a significant increase in the aboveground $\mathrm{N}$ status, and it was confined to a single harvest period. Support for the recommended rates of application (ANSI 2004) based on increases in fertilizer $\mathrm{N}$ uptake at the higher rate of application must be tempered. Substantial amounts of fertilizer $\mathrm{N}$ applied to each tree either accumulated in nontarget sinks (e.g., soil matrix, microbial biomass), or was lost from the planting site. It is the specific nature of what happens to the unrecovered fertilizer $\mathrm{N}$ that is of concern. Fertilizer $\mathrm{N}$ immobilized within the soil microbial biomass represents a slow-release, long-term nutrient pool. However, there is mounting evidence that chronic, high-dose additions of $\mathrm{N}$ adversely affects soil microbial populations and their ability to immobilize readily available $\mathrm{N}$, alters soil chemistry, and negatively affects tree growth (Wallenstein et al. 2006). Consequently, the low recovery rates observed in this study suggest $\mathrm{N}$ fertilization in accordance with the ANSI standards may become increasingly worrisome if applications are made on an annual basis. If the majority of the unaccounted for fertilizer $\mathrm{N}$ is lost from the site of application through leaching and/or gaseous emissions the concern for environmental degradation is immediate. The consistency of fertilizer recovery rates suggests both rates of application should be carefully considered in landscapes with a shallow depth to groundwater, adjacent to surface bodies of water, or possess soil qualities prone to leaching (i.e. coarse texture).

The ANSI A-300 standards for the fertilization of landscape trees (2004) explicitly state the application of fertilizers is a prescription that must be based on an understanding of the targeted plants' biology, impact to the environment, and desired management objective(s). The isotopic enrichment of the fertilizer used in this study provided unique and much-needed insights into our understanding of the biology and fate of fertilizer $\mathrm{N}$ applied at rates consistent with tree care standards. In addition to defining the extent of recovery for a fast release fertilizer, the study provided direction for continued fertilizer research. For instance, the dynamic nature of $\mathrm{N}$ partitioning and storage between above and below ground tissues requires examinations be extended well into the dormant period. Similarly, it is unclear 
if an equivalent amount of $\mathrm{N}$ applied over multiple applications using low doses of $\mathrm{N}$ or slow release fertilizers would yield similar results. The combination of a plethora of tree species found in urban landscapes, the myriad of soil and climatic conditions, and a wide range of management objectives have made attempts to generalize fertilizer recommendations difficult. It is essential that future studies utilize a wider array of tree species, fertilizer formulations, and treatment levels, as well as incorporate repeated applications within a growing season under a variety of site conditions to build upon the results from this study.

Acknowledgments. This research was funded by the International Society of Arboriculture's TREE Fund, the Wisconsin Arborist Association, and a University of Wisconsin System Consortium grant. Use of trade names in this publication does not imply endorsement by the University of WisconsinMadison of products named, nor criticism of similar ones not mentioned. Technical assistance of Drs. Brian Yandell and Jun Zhu, Mr. William Schmitt, Armand Krueger, and Peter Crump is gratefully acknowledged. Special consideration is given to The Morton Arboretum, Lisle, IL and Dr. Gary Watson for providing a research location and staff and the Root Control, Inc. for their donation of planting bags. From a dissertation submitted by L.P. Werner in partial fulfillment of the requirements for the Ph.D. degree.

\section{LITERATURE CITED}

Aerts, R. 1996. Nutrient resorption from senescing leaves of perennials: Are there general patterns? Ecology 84:597-608.

Ågren G.I., and O. Franklin. 2003. Root: shoot ratios, optimization and nitrogen productivity. Annals of Botany 92:795-800.

American National Standards Institute (ANSI). 2004. A300 American National Standard For Tree Care Operations: Fertilization Standard Practices, Part 2. Tree Care Industry Association, Inc., Manchester, NH. 12 pp.

Brinkman, J.A., and R.J. Boerner. 1994. Nitrogen fertilization effects on foliar nutrient dynamics and autumnal resorption in maidenhair tree (Ginkgo biloba L.). Journal of Plant Nutrition 17:433-443.

Chapin, III., F.S., and R.A. Kedrowski. 1983. Seasonal changes in nitrogen and phosphorus factions and autumnal retranslocation in evergreen and deciduous taiga trees. Ecology 64:376-391.

Colangelo, D.J., and M.H. Brand. 2001. Nitrate leaching beneath a containerized nursery crop receiving trickle or overhead irrigation. Journal of Environmental Quality 30:1564-1574.

Cornelissen, J.H.C., M.J.A. Werger, P. Castro-Diez, J.W.A. van Rheenen, and A.P. Rowland. 1997. Foliar nutrients in relation to growth, allocation and leaf traits in seedlings of a wide range of woody plant species and types. Oecologia 111:460-469.

Dirr, M.A. 1998. Manual of Woody Landscape Plants: Their Identification, Ornamental Characteristics, Culture, Propagation, and Uses. 5th edition. Stipes Publishing Co., Champaign, IL. 1187 pp.

Engelsjord, M.E., B.E. Branham, and B.P. Horgan. 2004. The fate of nitrogen-15 ammonium sulfate applied to Kentucky bluegrass and perennial ryegrass turfs. Crop Science 44:1341-1347.

Escudero, A., and S. Mediavilla. 2003. Decline in photosynthetic nitrogen use efficiency with leaf age and nitrogen resorption as determinants of leaf life span. Ecology 91:880-889.
Feigenbaum, S., H. Bielorai, Y. Erner, and S. Dasberg. 1987. The fate of ${ }^{15} \mathrm{~N}$ labeled nitrogen applied to mature citrus trees. Plant and Soil 97:179-187.

Gomez, L., and M. Faurobert. 2002. Contribution of vegetative storage proteins to seasonal nitrogen variations in the young shoots of peach trees (Prunus persica L. Batsch). Journal of Experimental Botany 53:2431-2439.

Gough C.M., J.R. Seiler, and C.A. Maier. 2004. Short-term effects of fertilization on loblolly pine (Pinus taeda L.) physiology. Plant, Cell, and Environment 27:876-886.

Gross, C.M., J.S. Angle, and M.S. Welterlen. 1990. Nutrient and sediment losses from turfgrass. Journal of Environmental Quality 19:663-668.

Harris, R.W. 1992. Root-shoot ratios. Journal of Arboriculture 18:39-42.

Hauck R.D., and J.M. Bremner. 1976. Use of tracers for soil and fertilizer nitrogen research. Advances in Agronomy 28:219-266.

Hoch, W.A., E.L. Singsaas, and B.H. McCown. 2003. Resporption protection: Anthocyanins facilitate nutrient recovery in autumn by shielding leaves from potentially damaging light levels. Plant Physiology 133:1296-1305

Horgan, B.P., B.E. Branham, and R.L. Mulvaney. 2002. Mass balance of ${ }^{15} \mathrm{~N}$ applied to Kentucky bluegrass including measurement of denitrification. Crop Science 42:1595-1601.

Huett, D.O. 1996. Prospects for manipulating the vegetative-reproductive balance in horticultural crops through nitrogen nutrition: A review. Australian Journal of Agricultural Research 47:47-66.

Illinois State Water Survey. 2002. Illinois Climate Network Data Archive. Accessed May 5, 2003. <http://www.sws.uiuc.edu/warm/ data/archive.asp>.

International Atomic Energy Agency (IAEA). 1983. A Guide to the Use of Nitrogen-15 and Radioisotopes in Studies of Plant Nutrition: Calculations and Interpretations of Data. IAEA, Vienna, Austria.

Kandeler, F., C. Kampichler, and O. Horak. 1996. Influence of heavy metals on the functional diversity of soil microbial communities. Biology of Fertile Soils 23:299-306.

Kosola, K., D.I. Dickmann, E.A. Paul, and D. Parry. 2001. Repeated insect defoliation effects on growth, nitrogen acquisition, carbohydrates, and root demography of poplars. Oecologia 129:65-74.

Kraimer, R.A., W.C. Lindemann, E.A. Herrera, and B. McCaslin. 2001. Fate of ${ }^{15} \mathrm{~N}$-labelled fertilizer applied to pecan. Proceedings of the Western Nutrition Management Conference 4:237-246.

Littell, R.C., G.A. Milliken, W.W. Stroup, and R.D. Wolfinger. 2004. SAS System for Mixed Models. 6th edition. SAS Institute, Cary, NC. $633 \mathrm{pp}$.

Lovett, G.M., and P. Tobiessen. 1993. Carbon and nitrogen assimilation in red oaks (Quercus rubra L.) subject to defoliation and nitrogen stress. Tree Physiology 12:259-269.

Manter, D.K., K.L. Kavanagh, and C.L. Rose. 2005. Growth response of Douglas-fir seedlings to nitrogen fertilization: Importance of Rubisco activation state and respiration rates. Tree Physiology 25: $1015-1021$

Martinez, J.M., J. Banuls, A. Quinones, B. Martin, E. Primo-Millo, and F. Legaz. 2002. Fate and transformations of ${ }^{15} \mathrm{~N}$ labeled nitrogen applied in spring to citrus trees. The Journal of Horticulture Science and Biotechnology 77:361-367.

Masarik, K.C. 2003. Monitoring water drainage and nitrogen leaching below different tillage practices and fertilization rates. M.S. Thesis. University of Wisconsin-Madison, Madison, WI.

Mattos, D., D.A. Graetz, and A.K. Alva. 2003. Biomass distribution and nitrogen-15 partitioning in citrus trees on a sandy entisol. Soil Science Society of America Journal 67:555-563. 
Meerts, P. 2002. Mineral nutrient concentrations in sapwood and heartwood: A literature review. Annals of Forest Science 59:713-722.

Miller, R.W. 2003. Practical application: Are we asking the right question and looking in the right places, pp. 15-20. In: Siewert A., A. Siewert, B. Rao, and D. Marion (Eds.). Tree and Shrub Fertilization: Proceedings from an International Conference on Tree and Shrub Fertilization. International Society of Arboriculture, Champaign, IL.

Neely, D. 1980. Tree fertilization trials in Illinois. Journal of Arboriculture 6:271-273.

Neely, D., E.B. Himelick, and W.R. Crowley, Jr. 1965. Experimental field studies on shade tree fertilization. Illinois Natural History Survey Bulletin No. 53(4).

Neilsen, D., P. Millard, G.H. Neilsen, and E.J. Hogue. 2001. Nitrogen uptake, efficiency of use, and partitioning for growth in young apple trees. Journal of the American Society for Horticulture Science 126:144-150.

Perakis, S.S., J.E. Compton, and L.O. Hedin. 2005. Nitrogen retention across a gradient of ${ }^{15} \mathrm{~N}$ additions to an unpolluted temperate forest soil in Chile. Ecology 86:96-105.

Perry, E., and G.W. Hickman. 1998. Correlating foliar nitrogen levels with growth in two landscape tree species. Journal of Arboriculture 24:149-153.

Pregitzer, K.S., D.I. Dickmann, R. Hendrick, and P.V. Nguyen. 1990. Whole-tree carbon and nitrogen partitioning in young hybrid poplars. Tree Physiology 7:79-93.

Preston, C.M., and D.J. Mead. 1994. Growth response and recovery of ${ }^{15} \mathrm{~N}$-fertilizer one and eight growing seasons after application to lodgepole pine in British Columbia. Forest Ecology and Management 65:219-229.

Rose, M.A. 1999. Nutrient use patterns in woody perennials: Implications for increasing fertilizer efficiency in field-grown and landscape ornamentals. HortTechnology 9:613-617.

Rose, M.A., and B. Biernacka. 1999. Seasonal patterns of nutrient and dry weight accumulation in Freeman maple. HortScience 34:91-95.

Salifu, K.F., and V.R. Timmer. 2003. Nitrogen retranslocation response of young Picea mariana to nitrogen-15 supply. Soil Science Society of America Journal 67:309-317.

Scholberg, J.M.S., L.R. Parsons, T.A. Wheaton, B.L. McNeal, and K.T. Morgan. 2002. Soil temperature, nitrogen concentration, and residence time affect nitrogen uptake efficiency in citrus. Journal of Environmental Quality 33:759-768.

Smith, E.M. 1978. Fertilizing trees and shrubs in the landscape. Journal of Arboriculture 4:157-161.

Struve, D.K. 1995. Nitrogen, phosphorus, and potassium recovery of container-grown red oak and black gum seedlings under different fertilizer application methods. Journal of Environmental Horticulture 13:169-175

Struve, D.K., and M.A. Rose. 1998. Early-season fertilization reduces fertilizer use without reducing plant growth. Journal of Environmental Horticulture 16:47-51.
United States Department of Agriculture. 1978. Soil Survey of Columbia County, Wisconsin. Department of Agriculture Soil Conservation Service, Washington, D.C.

United States Department of Agriculture. 2000. Soil Survey of Du Page County, Illinois. Department of Agriculture Soil Conservation Service, Washington, D.C.

van de Werken, H. 1981. Fertilization and other factors enhancing the growth rate of young shade trees. Journal of Arboriculture 7:33-37.

van de Werken, H. 1984. Fertilization practices as they influence the growth rate of young shade trees. Journal of Environmental Horticulture 2:64-69.

Wallenstein, M.D., S. McNulty, I.J. Fernandez, J. Boggs, and W.H Schlesinger. 2006. Nitrogen fertilization decreases forest soil fungal and bacterial biomass in three long-term experiments. Forest Ecology Management 222:459-468.

Warren, S.L. 1993. Growth and nutrient concentration in flowering dogwood after nitrogen fertilization and dormant root pruning. Journal of Arboriculture 18:57-63.

Werner, L.P. 2000. Nitrogen relations of ornamental trees in urban soils: A first look. M.S. Thesis, University of Wisconsin-Stevens Point, Stevens Point, WI.

Werner, L.P. 2008. ${ }^{15} \mathrm{~N}$ as a Tracer to Evaluate the Fate of Fertilizer N in Common Hackberry (Celtis occidentalis L.) Trees in the Urban Landscape. Ph.D. dissertation. University of Wisconsin-Madison, Madison, WI.

White, C.S., and M.J. McDonnell. 1988. Nitrogen cycling processes and soil characteristics in an urban versus rural forest. Biogeochemistry 5:243-262.

Wisconsin State Climatology Office. 2002. Arlington University Farms (470308). Accessed May 5, 2005. http://www.aos.wisc.edu/ sco/ clm-history/stations/470308.

Wyman, D. 1936. Growth experiments with pin oaks which are growing under lawn conditions. Cornell University Agricultural Experiment Station Bulletin 646.

\section{L.P. Werner (corresponding author)}

Associate Professor

College of Natural Resources-Forestry

1600 Franklin Street

University of Wisconsin-Stevens Point

Stevens Point, WI 54481, U.S.

\section{L.G. Jull}

Associate Professor and Extension Specialist

Department of Horticulture

1575 Linden Drive

University of Wisconsin-Madison

Madison, WI 53706-1590, U.S. 
Zusammenfassung. Doppelt angereichertes Ammonium-Nitrat mit $15 \mathrm{~N}$ Isotop (1,5 atom\%) wurde verwendet, um Dünger N Erholung, N Partitionierung und über Grund N-Status von containergezogenen Celtis occidentalis-Bäumen zu bewerten, die mit natürlich gewachsenem Boden an den Standorten Arlington, Wisconsin und Lisle in Illinois, USA verfüllt waren. Die behandlungen bestanden aus $0,1.42 \mathrm{gN}$ Baum -1 und $4.27 \mathrm{~g} \mathrm{~N}$ Baum -1, dem Flächenäquivalent von $0,0.49$ und 1.47 kg N 100m-2. Die Bäume wurden 14, 3060 und 90 Tage nach der Düngung geerntet. Durch den Dünger verursachteVeränderungen in dem über Gund N-Status waren nur in der Behandlung mit $4.27 \mathrm{~g}$ Baum -1 deutlich. Die Menge des N-Düngers in oberirdischen Geweben stieg mit der Rate der Applikation. Dünger N war vorzugsweise verteilt auf Blattwerk und diesjährigem Stammgewebe. Der Prozentsatz von Dünger aus oberirdischem Gewebe differierte nicht zwischen den Applikationsraten, die in Arlington, Wisconsin bei 15\%-25\% und 5\%-9\% in Lisle in Illinois betrugen. Frostschaden an den Blättern am Standort Lisle in Illinois könnte eine Ursache für die lokalen Unterschiede in der Biomasse gewesen sein, welche die Stickstoffaufnahme und Umbau beeinflusste. Diese Daten verdeutlichen, dass Dünger $\mathrm{N}$ außerhalb des Zielgebiets akkumulierte und/oder dass es bei beiden Applikationen verloren ging.
Resumen. El nitrato de amonio (NH4NO3) doblemente enriquecido con el isótopo $15 \mathrm{~N}$ (1.5 átomo \%) fue usado para evaluar la recuperación del $\mathrm{N}$, la distribución del mismo, y el estado en el aire del $\mathrm{N}$ en el almez común de virginia (Celtis occidentalis L.) crecido en contenedor llenado con suelo nativo en Arlington, Wisconsin y Lisle, Illinois, U.S. Los tratamientos consistieron de $0,1.42 \mathrm{~g} \mathrm{~N}$ árbol-1 (0.05 onz) y $4.27 \mathrm{~g} \mathrm{~N}$ árbol-1(0.15 onz), el área equivalente de $0,0.49$, y $1.47 \mathrm{~kg} \mathrm{~N}$ $100 \mathrm{~m}-2$ (0, 1, y 3 libra N 1000 pie-2). Los árboles fueron cosechados 14, 30, 60 y 90 días después de la fertilización. Los cambios inducidos de fertilizante en el estado aéreo de $\mathrm{N}$ fueron significativos solamente en el tratamiento $4.27 \mathrm{~g} \mathrm{~N}$ árbol-1 (0.15 onz). La cantidad de $\mathrm{N}$ recobrado en los tejidos incrementó con la tasa de aplicación. El N fue preferentemente distribuido al follaje y la madera del tallo de la estación de crecimiento. El porcentaje de fertilizante recobrado en los tejidos no difirió entre las tasas de aplicación, variando de 15\%-25\% en Arlington, WI, y 5\%-9\% en Lisle, IL. El daño por heladas en el follaje en Lisle, IL puede haber resultado en diferencias de localidad en biomasa lo cual afectó la toma y recuperación del fertilizante de N. Estos datos sugieren que el fertilizante $\mathrm{N}$ acumulado en sumideros no objetivos fueron o no perdidos del sitio de aplicación en ambas tasas de aplicación. 